\title{
Complexity, variation and meaning: an integrated view on language and cognition*
}

Augusto Soares da Silva ${ }^{a}$

\begin{abstract}
The complexity of the linguistic system, the variability of meaning and the interindividuality of human cognition are intimately related. By examining language in its effective usage, we cannot help but recognize its great variability and heterogeneity, and one must correlate social variation with conceptual variation. When investigating the variability of meaning, one cannot neglect sociolinguistic variation as one of the factors of this variability, and it becomes inevitable to meet the multidimensionality of meaning in the confluence of its social and conceptual dimensions and in the correlation among perception, action and interaction. Understanding cognition as socioculturally situated makes it inevitable to integrate the social, cultural and interactional aspects in the analysis not only of cognitive capacities in general but also of language. In this study, we attempt to articulate the idea of language as a complex dynamic system with the ascertainment of the intrinsic flexibility of linguistic meaning, which has prototypicality as one of its greater manifestations, and we identify the need for the integration of conceptual and social aspects of language and cognition. We follow the theoretical framework of Cognitive Linguistics, and we argue for the need of advanced multivariate methods that can adequately approach language as a complex dynamic system and a multidimensionality of linguistic meaning.
\end{abstract}

Keywords: complex dynamic system; meaning variation; prototypicality; situated cognition; multivariate methods.

\footnotetext{
a Centro de Estudos Filosóficos e Humanísticos (CEFH). Universidade Católica Portuguesa. E-mail: assilva@braga.ucp.pt.
} 


\section{Introduction}

How systematic can a linguistic system be if the use of language is inevitable and significantly variable? How invariable can the meaning of a linguistic expression be when meaning is intrinsically dynamic and flexible? How individual or universal can human cognition be if the mind is situated in socioculturally determined contexts? These three fundamental questions on language and cognition lead to rethinking the notion of a language system and the nature of linguistic meaning and human cognition. In this study, we attempt to articulate the idea of language as a complex dynamic system with the ascertainment of the intrinsic flexibility of linguistic meaning, which has prototypicality as one of its greater manifestations, and we identify the need for the integration of conceptual and social aspects of language and cognition. We approach language in its effective use and follow the theoretical framework of Cognitive Linguistics (GEERAERTS; CUYCKENS, 2007, for an overview), which is defined as a usage-based model, a meaning-oriented model and an experiential model, that involves all of the dimensions of human experience - namely, individual, social and historic dimensions.

The complexity of a linguistic system, the variability of meaning and the interindividuality of human cognition are intimately related. By examining language in its effective usage, we cannot help but recognize its great variability and heterogeneity, and one must correlate two types of variation: social and conceptual. By investigating the variability of meaning, one cannot neglect sociolinguistic variation as one of the factors of this variability, and it becomes inevitable to meet the multidimensionality of meaning in the confluence of its social and conceptual dimensions and in the correlation among perception, action and interaction. Understanding cognition as socioculturally situated makes it inevitable to integrate the social, cultural and interactional aspects in the analysis not only of cognitive capacities in general but also of language.

We start by verifying that the inevitable variation in any language community implies abandoning the idealist conception of language as a homogeneous system, which was popularized by Saussure and Chomsky. More radically, it implies to desystematize the language system and to understand 
language as a complex dynamic system. Following up, we observe that to this same dynamic and complex idea there is, on the one hand, prototypicality - or prototy pe-based categorization - and other manifestations of the variability of linguistic meaning and, on the other hand, the situated embodiment or sociocultural situatedness of human cognition. We later identify different types of meaning variation, namely, semasiological variation (prototypicality and polysemy) and onomasiological variation (near-synonymy and synonymy), and we show, based on the semantic analysis of special expressions, that perception, action and interaction are dimensions of linguistic meaning. In the following section, we address the social aspects of linguistic meaning and the necessary integration of intralinguistic or lectal (dialectal, sociolectal, idiolectal) variation in the cognitive perspective of language. Finally, we advance the argument for the need of quantitative and multivariate advanced methods that can adequately approach language as a complex dynamic system and the multidimensionality of linguistic meaning.

\section{Language as a complex dynamic system}

The system of a language is inevitably nonhomogeneous. The reason is simple: linguistic variation is an immediate and inevitable consequence of language usage, which implies that a linguistic community can never be homogeneous; social variation is intrinsic to any community and, therefore, to any linguistic community.

What then is the system of a language? Because the usage of a language is inevitably variable, how systematic is a language system? How is it possible to define a language if its usage is intrinsically heterogeneous? Furthermore, because the usage variation is lectally structured, that is, organized in terms of dialects, sociolects and idiolects or registers, how systematic is this variation?

The primary fact of linguistic study is the linguistic behavior of speakers, that is, their verbal interaction. It is the interaction between individual speakers that a linguist can observe and directly describe. We are, naturally, led to think that there is some structure that underlies the individual linguistic behavior of speakers: (i) on an individual level, there is a structure in the sense that each individual has their 
own internal language system and their own knowledge of language; and (ii) on an interindividual level, there is a structure that is something shared by the different speakers of a community. However, what we usually think of and designate as a language system is something abstract that a linguist infers from the observation of language usage. Accordingly, the system is a secondary abstraction that intends to present the regularities of language usage. The linguistic system is not directly accessible but is acquired through abstraction both for the linguists, whose aim is to describe a language system, and for the speakers, whose target moves towards the process of learning the system of a language.

How is it then possible that speakers learn, as children or adults, the system of a language if the system is not directly accessible? Speakers learn their language system through mutual alignment with one another. This means that they learn through imitation and adaptation, necessarily at the level of interaction. The linguistic alignment of speakers is incomplete, as it is not possible to interact with all the speakers of a language but only with a small part. This is why communicative interactions not only are social events but also reflect a social structure comprised of groups and social networks to which individual speakers belong and that establish these verbal interactions.

Consequently, lectal variation is an integral part of a usage-based conception of a linguistic system (cf. GEERAERTS, 2010b). A language is, after all, a cluster of different lectal varieties and a cluster of subsystems in the abstract conception of language. So far, we have abandoned the Saussurean and Chomskyan idea of language as a homogeneous system and substituted it with the idea of a heterogeneous linguistic system that is polylectal, or multilectal, from Labov's (1972) variationist sociolinguistics. However, the assumption of a usage-based model of language should take us to a more dynamic view on language, namely, to an idea of language as a heterogeneous system in a more radical sense.

Because a language is a nonhomogeneous reality, would its dialects, sociolects and idiolects, in a general sense, its lects, be internally homogeneous? No, they would not. Chambers and Trudgill (1998) have already observed that the linguistic varieties are part of a dialectal continuum, in which the adjacent 
varieties are mutually comprehensible, but the variants from the open-ends of the chain may not be. In terms of the Prototype Theory (TAYLOR, 1995; GEERAERTS, 1997) - a categorization model developed by Cognitive Linguistics -, lectal variations constitute categories based on prototypes, which means that some instantiations are more typical, more prominent, and "better examples" of certain linguistic variety than others. Consequently, some instantiations, i.e., some variables, are more central or closer to the prototypical center and others are further away from it, because the last ones can enter intersecting areas with instantiations or variables from other linguistic varieties. That is, each lectal variety presents a radial structure from a certain prototypical center.

In this more radical sense of linguistic heterogeneity, each language is a complex dynamic system, and in this system, each expression, each construction, each word, and each linguistic form has its own lectal distribution (GEERAERTS, 2010b). This lectal distribution is inevitably multifactorial, as it involves not only geographic differences but also many other lectal factors, which are social, stylistic or even the speaker's characteristics. Furthermore, these various lectal factors interact with the conceptual factors.

The necessary deconstruction of the notion of a language system or, specifically, the necessary desystematization of the linguistic system involves two essential arguments: if "the language" exists as a system, then it can only exist as a complex dynamic system; and if the lectal varieties exist as separated entities within this complex dynamic system, then they can only exist as prototypical categories or categories that have an internal structure based on prototypes. When this desystematization of a language system has a larger descriptive and methodological consequence, the systematic inclusion of lectal variation in the description of any linguistic expression and the use of multivariational methods can account for the heterogeneity and multifactoriality of linguistic phenomena (cf. GEERAERTS, 2010b).

\section{Flexibility of meaning and social cognition}

After defining language as a complex dynamic system, two other key concepts should also be defined: linguistic 
meaning and how (in)variable it is and individual cognition and how (inter)individual it is.

Linguistic meaning is intrinsically dynamic, flexible, encyclopedic, non-autonomous, and based on usage and experience, and it identifies with conceptualization, in the most general meaning of any mental experience. These properties of meaning, which are explored by Cognitive Linguistics, are evident, for example, not only in the phenomena of polysemy and semantic change (SILVA, 1999; 2003; 2006) but also in grammatical constructions as expressions of conceptual perspectivation and, thus, of alternative perspectives to conceptualize each situation (LANGACKER, 1987; 1991; 2008; TALMY, 2000).

Let us observe more closely the dynamic and flexible nature of linguistic meaning. The flexibility of meaning comes from the fact that meaning represents the world, and the world can be a changing reality. Thus, new experiences imply that we adapt our categories to the transformation of circumstances and that we open the way to nuance and deviant cases. In more conceptual terms, the flexibility of meaning is an effect of the way that we categorize the world. We do it not as properties that necessarily apply to all members of a certain category and sufficient to distinguish this category from other categories, as the "classical" theory of categorization assumes, but based on prototypes or mental representations of the properties and examples that we consider to be more representative in our cultural and social contexts, as Prototype Theory proposes, the way that it has been developed by Cognitive Psychology (ROSCH, 1978) and by Cognitive Linguistics (GEERAERTS, 1985; 1997; TAYLOR, 1995). Categorizing based on prototypes is categorizing through similarity or associations in some way with the prototype, through which the members of a category that present varying degrees of representativeness or prominence are grouped through partial similarities or family resemblance (WITTGENSTEIN, 1953), and the borders within a category and between categories are usually diffuse. More concrete categories such as fruit, bird and color ( $\mathrm{ROSCH}$, 1978) or more abstract categories such as lie (COLEMAN; KAY, 1981) or the verb deixar 'to leave, to let' (SILVA, 1999) all display effects of prototypicality. 
The main reason for prototypicality is based on the categories of the human cognitive system itself and its mode of functioning. A category that is based on prototypes meets the following three requirements of cognitive efficiency (GEERAERTS, 1988): (i) informative density, as maximum information can be achieved with minimal effort; (ii) flexibility, as the speakers can adapt the category to new circumstances and experiences and integrate them in it; and (iii) structural stability, as new facts can be interpreted through preexisting knowledge and, thus, the aforementioned flexibility does not make the category communicatively inefficient. Prototypical categories make the conceptual system more economic and have the immense advantage not only of adapting easily to the inevitable variation and change but also of working as interpretative models of the new conditions, situations and needs.

The prototypicality of conceptual and linguistic categories and its effects, namely, the category structure in the form of radial networks or the semantic extension through conceptual metaphor and metonymy and its subsequent polysemy, match perfectly with the idea of language as a complex dynamic system that was developed in the previous section. In fact, the very characteristics of the linguistic system - dynamism, adaptability, complexity and multisystemicity - are macroeffects of prototypicality.

Let us now approach the concept of cognition. Can we conceive of cognition without interaction? Can we continue taking individual internal thought as having some type of pre-eminence over the supraindividual external activity or over the thought that leads to (inter)action? Can we understand the embodiment hypothesis of thought and language developed by Lakoff \& Johnson (1999) in the individual and universal or physical and neurophysiological sense of human cognition?

In the last twenty years or more, there has been some significant enlargement of the concept of cognition: from a purely internal and autonomous perspective, which is summarized in the (metaphorical) idea of cognition as a brain, with the "first generation of the cognitive sciences", to the perspective of the embodiment of cognition or its integration in the ensemble of the physical body of an individual (VARELA; THOMPSON; ROSCH, 1991; EDELMAN, 1992; DAMÁSIO, 1995; 2000; LAKOFF; JOHNSON, 1999; GIBBS, 2005), with the "second 
generation of the cognitive sciences", and more recently, to the inclusion of the situation and interindividuality in cognition and, thus, the notion of situated cognition or social cognition (ZLATEV, 1997; 2007; TOMASELLO, 1999; BERNÁRDEZ, 2004; 2005; 2008a; 2008b; ZIEMKE; ZLATEV; FRANK, 2007; FRANK; DIRVEN; ZIEMKE; BERNÁRDEZ, 2008; ZLATEV; RACINE; SINHA; ITKONEN, 2008; PISHWA, 2009; HARDER, 2010). As an example, the neuroscientist Wilson (2005) speaks of a collective mind and a social brain, which suggests that our brain is specially prepared to establish connections with other brains for interactive behaviors and that cognition is either individual as well as collective.

It is necessary to complement two concepts that have been well-seen in the cognitive sciences, namely, the older and more popular concept of embodiment, or the bodily and sensorimotor basis of the mind, cognition and language, and the more recent concept of sociocultural situatedness, i.e., the ways in which individual minds and cognitive processes are shaped by social and cultural interactions. That is, it is important to understand the more popular concept of embodiment with this double meaning as situated embodiment (cf. ROHRER, 2007). The investigation of the last few years in a number of cognitive sciences explores the complementarity of these concepts in the interdisciplinary context of studies about situated cognition, which contribute to a change of paradigm. As the philosopher Andy Clark wrote more than a decade ago

\begin{abstract}
talk of embodiment and situatedness has become increasingly frequent in philosophy, psychology, neuroscience, robotics, education, cognitive anthropology, linguistics, and in dynamical systems approaches to behavior and thought. There is clearly a shift in thinking but the nature and importance of the shift is surprisingly hard to pin down (CLARK, 1999, p. 345)
\end{abstract}

Two emerging tendencies in the framework of Cognitive Linguistics have contributed to integrating the social aspects in the cognitive perspective of language, specifically, Biocultural Linguistics (SINHA, 2010) and Cognitive Sociolinguistics (KRISTIANSEN; DIRVEN, 2008), which we discuss in section 6.

Accordingly, cognition is situated, since cognitive activity always occurs in a sociocultural context; cognition is distributed, through the division of cognitive effort between 
two or more individuals and among them and their cognitive instruments; cognition is synergic (BERNÁRDEZ, 2008 a; 2008 b), as an activity of collaboration between individuals who are not only synchronic but also, above all, sociohistoric, whose mechanisms are imitation, as the more recently discovered "mirror neurons".

\section{Meaning variation: semasiological and onomasiological variation}

How does meaning vary and what are the types of meaning variation? Let us consider the case of lexical meaning, which we use as a model for other types of semantic variation. The fundamental distinction, which goes back to the seminal study from Baldinger (1964), opposes semasiology and onomasiology: semasiology starts from a word or another expression to analyze the different meanings associated with it, whereas onomasiology starts from the concept or the function and investigates the different words or expressions that designate it. Meaning variation can thus be semasiological or onomasiological.

Lexical choices in discourse are determined by different factors. Obviously, there are lexical choices of (more or less) specific concepts determined by the theme of the speech, but there are others that concern sociolinguist, stylistic or pragmatic differences, not differences between concepts. The choice, for instance, between guarda-redes and goleiro ("goalkeeper") is a choice between forms that express the same concept but that belong to different national varieties (guardaredes is the term used in European Portuguese, while goleiro is used in Brazilian Portuguese). The choice between morrer and falecer ("to die") is a choice between forms that express the same concept but that are stylistically different (falecer is used in formal registers). The choice between você and o senhor ("you") is a choice between forms that express the same concept but that are pragmatically different. We can call this variation between denotational synonyms formal onomasiological variation, as opposed to conceptual onomasiological variation, that involves conceptual differences such as the difference between guarda-redes/goleiro ("goalkeeper") and jogador ("player"). Distinguished from onomasiological variation between 
different alternative expressions to designate a certain concept or function is semasiological variation, to which the phenomenon of prototypicality, discussed in the previous section, is linked. Semasiological variation involves polysemy and vagueness and thus indicates the choice between different senses and/ or referents of certain words or expressions. ${ }^{1}$ A fourth type of lexical variation is contextual variation, which involves all the aspects of a communicative situation - not only the more or less permanent characteristics of the speaker (such as being Portuguese or Brazilian), but also the more transitory and interactional characteristics of the speech act (such as the discourse genre, for example). Therefore, the distinction between conceptual variation, which involves conceptual differences, and social variation, which is linked to the social aspects of the meaning, is as fundamental as the distinction between semasiological and onomasiological variation.

As to the development of lexical semantics, it should be noted that Cognitive Semantics constitutes a descriptive expansion in relation to other semantic theories, such as Structural Semantics and Generative Semantics: from the traditional interest in the lexical structures (lexical fields, lexical taxonomies and lexical relations, as introduced by Structural Semantics) to the interest in the phenomena of lexical salience; and from the initial interest in semasiology (Cognitive Semantics was initially focused on polysemy) to the development of onomasiology and the identification of different types of onomasiological salience (cf. GEERAERTS, 2010a). The wider development, to which Cognitive Semantics has largely contributed, concerns the study of the phenomena of semasiological and onomasiological lexical salience. Studying lexical salience is, in fact, studying the interaction between structure and usage, as salience is the manifestation of usage in the structure - some parts are more important than other parts exactly because they are used more frequently.

We can distinguish different types of lexical salience

1 For the types of to the empirical study of Geeraerts, Grondelaers, Bakema (1994), who should be credited for the distinction between conceptual o n o m a s i log i c a 1 variation and formal o n o m a s i log i c a 1 variation. 
semantic coherence, than others. For example, the apple, the orange or the pear are more prominent referents of the word fruit than the lemon, the pomegranate or the coconut; and the senses of 'to abandon' and 'to allow' are more prominent of the verb deixar than the sense of 'to go away' (SILVA, 1999). The salience on conceptual onomasiological variation implicates the so-called basic level of the lexical hierarchies and with the entrenchment (LANGACKER, 1987, p. 59-60) of certain lexical items in relation to other lexical items from the same paradigm. For example, skirt and pants are categories of a basic level and are more prominent than mini-skirt and jeans. The salience in formal onomasiological variation consists of the sociolinguistic prevalence among denotational synonyms, which means that certain terms are geographically, socially or stylistically more prominent than their synonyms.

Another crucial fact is that the four types of aforementioned lexical variation can be combined in different ways. For example, the variation between deixar and abandonar (cf. SILVA, 1999) is conceptual, from the difference in the intensity of abandonment (stronger in abandonar than in deixar), and it is also formal, from the emotive and stylistic differences (abandonar is more emotive and more stylistically marked than deixar). In contrast, onomasiological variation and semasiological variation can be mutually conditioned: for example, the entry of the verbs allow and abandon at the end of Old Portuguese was one of the main factors in the continuous restructuring of the prototypical centers of deixar, and these prototypical restructurings contributed to the differentiation of the three verbs (SILVA, 1999). The choice of an (in)formal term can correlate with conceptual factors: for example, we use more informal words for familial than for scientific themes. Lectal variation can correlate with conceptual factors: for example, less frequent, vague, new or negatively emotive concepts tend to be expressed through more dialectal synonyms (GEERAERTS; SPEELMAN, 2010). Additionally, conceptual choices can also be determined by social factors.

What happens with lexical meaning can also be verified in the grammatical meaning. In constructional variation, we can distinguish among the conceptual onomasiological variation (alternative constructions express different functions), the formal onomasiological variation (alternative constructions 
express the same function), the semasiological variation (different senses or functions of a construction) and the contextual variation. Conceptual, formal or contextual factors can determine the choices among constructions. For example, the choice between mono-clausal infinitival completive construction (the so-called "clause union") and the biorational infinitival completive construction, which are both selected by causative verbs and verbs of perception, is determined by conceptual factors (the degree of event integration and agentivity of the main subject) and/or lectal factors (the monoclausal construction is more productive in the European variety than in the Brazilian variety - see SILVA, 2005).

The lexical and grammatical choices are therefore based on one or more of the three factors of meaning, form and context. It is the same as saying that meaning, form and context are three sources of semantic variation. It is important to emphasize that the formal onomasiological variation, lexical or constructional, is a sociolinguistic variable and is permeable, as any sociolinguistic variable, to a group of extralinguistic variables, such as social class, age, sex, geographical origin, social group, register, etc. Denotational, lexical or functional synonyms are interesting from the sociolinguistic point of view, as regional, social, stylistic and pragmatic differences are identified, and these differences motivate the existence and competition of language varieties (cf. SILVA, 2010).

Another semantic problem that is involved in linguistic variation is the equivalence of meaning, a prerequisite of the notion of a sociolinguistic variable. ${ }^{2}$ To what extent can the notion of a sociolinguistic variable, which originates in phonology, be applied to the lexicon and grammar? How can semantic equivalence be established between lexical items and morphological or syntactic constructions? In relation to lexical items as items related for example to clothing or football, we can control their concrete referents. This is

${ }^{2}$ See the initial debate between Lavandera (1978) and Labov (1978). Lavandera (1978, p. 171) argues that applying the notion of sociolinguistic variable to the domains of lexicon, morphology and syntax requires an "articulated theory of meanings". more difficult in relation to linguistic functions. Even if we restrict the constructional variants to the same syntagmatic context, the complete functional equivalence cannot occur in natural languages: there are always differences of conceptual perspectivization, as the cognitive grammatical models of Langacker (1987; 1991; 2008) and Talmy (2000) demonstrate. An attempt to answer the problem of semantic equivalence 
and the notion of a sociolinguistic variable, which is more difficult to determine in the grammatical domain, is the following: if the semantic differences among constructional variants are stable among linguistic variants, then any remaining variation is sociolinguistic. Szmrecsanyi (2010) and Colleman (2010) offer two interesting case studies about sociolinguistic determinations in alternative constructions of genitives in English ( $o f$ and 's) and ditransitives verbs in Dutch, respectively.

\section{Perception, action and interaction and the problem of universal concepts}

It is frequent to see in Cognitive Linguistics and other cognitive sciences some tension between cognitive and social, individual and interindividual, perception and interaction, and neural and cultural. Two main reasons can explain these tensions and, in fact, why these classic dualisms are maintained. One reason comes from the cognitive perspective, which sees language from a psychological point of view, as part of the organization of knowledge in the individual mind. Another reason that has already been discussed here involves the very conception of human cognition - more specifically, the tendency of focusing on the individual and universal dimensions of cognition and its physical and neurophysiological sides. A sociocognitive agenda and the systematic integration of the social aspects in the agenda of Cognitive Linguistics thus become tasks of highly difficult realization.

Is the sensorial perception experientially and conceptually disconnected from the motor action and social interaction? Are the image schemas or patterns of our sensorimotor activity and our perception of action and events, as popularized by Cognitive Semantics (JOHNSON, 1987; HAMPE, 2005), individual and universal phenomena? Are there universal concepts?

Let us focus on image schemas and the semantics of space. Because of the human perceptual apparatus, we perceive the topology of objects. However, at the same time, we are conscious of the movement of objects and the interaction with them and project interests and specific objectives on real-life situations. This means that perceiving the world is (inter)acting with it, as Merleau-Ponty (1945) has already pointed out in 
his phenomenology of perception. According to MerleauPonty (1945), perception, movement and interaction co-occur as a single phenomenon. A number of studies on Cognitive Semantics about spatial semantics identify the projected and social aspects of the spatial meanings of linguistic expressions. Let us examine some examples.

Clark (1973) considers that we perceive space following four parameters: physical space, which implies perceiving the three dimensions; geological space, which results from perceiving gravity; biological space, which is defined in relation with the human body; and social space, or the faceto-face interaction with one another. The confluence of these parameters determines the perceptual space, which is, by nature, universal. In addition, linguistic space concerns the linguistic means used to conceptualize the perceptual space and it is specific to each language.

Deane (1993) proposes a multimodal conception of the meaning of prepositions, considering that human beings perceive and conceptualize the following three aspects of space: the visual space, which corresponds to Clark's physical space; the control space, which corresponds to the biological and social spaces; and the kinetic space or the space of dynamic interaction. Deane suggests that these three modes of perception occur simultaneously, that they are prelinguistic and also part of the bodily human experience.

Talmy $(1983 ; 2000)$ develops a model of Cognitive Semantics of space that comprises, beyond location and meaning, various biosocial aspects, such as intentionality, the conceptualizer's perspective and point of view, and the force-dynamic patterns of interaction between the participants.

In accordance with Clark, Deane and Talmy, Vandeloise (1991; 2003) elaborates a model of spatial semantics based on the confluence of three experiential factors as follows: the perception of topological arrangements, which is determined by human perceptual capacities; kinetics, or sensorimotor experience, which is determined by human motor capacities; and the interaction or assimilation of context and accommodation of the body, determined by social interaction.

This all means, then, that spatial meanings go beyond mere location and mere movement and integrate perceptual, kinetic and interactional aspects. This also means that image 
schemas are complex primitives (cf. VANDELOISE, 2003; CORREA-BENINGFIELD et al., 2005), as they involve not only the dimension of perception but also the dimensions of action and interaction. For example, the image schema of containment goes beyond the topological inclusion, and brigs elements of force and functional elements (VANDELOISE, 1991; 2003). In addition, certain image schemas can be elaborations of others, and the ones that are apparently more primitive, such as topological schemas, are not primitive after all. Vandeloise (2003), for example, shows that containment and support are functional elaborations of control in more than one direction or on the vertical axis.

Let us now focus on apparently universal concepts that are, nonetheless, intimately related to culture. The chosen concepts are "cause", "verbs of perception" and "parts of the body".

"Cause" is not an indecomposable concept or a semantic primitive, but a mental construction grounded trough experience. In Western culture, "causation is forced movement" is the preferred metaphor for understanding the concept of cause (LAKOFF; JOHNSON, 1999). In reality, we conceptualize causes metaphorically as forces and causation in terms of the movement of an entity forced by another entity, from one place to another. However, there are other metaphors and other cultural models of cause, such as the following (BERNÁRDEZ, 2008, p. 326-335; SILVA, 2004; 2005a).

- "causation is temporal precedence": the cause of an event is what (generally) precedes this event; this is why prepositions and conjunctions of temporal value are generally also used with causal meaning, for example, the conjunction and preposition since in English or the preposition segundo in Portuguese.

- "causation is accompaniment": the cause of an event is the main phenomenon that occurs with this event, for example, the sun is the cause of light. Otherwise, cause is something that accompanies someone or some other thing. This is how cause is conceptualized in Navajo (BERNÁRDEZ, 2008, p. 344-347).

- "causation is possession and location": the cause of an event is the possessor of this event and the propriety is location, for example, the sun possesses light. 
- "causation is progeneration": cause corresponds to the parents, and effect corresponds to the offspring (TURNER, 1987, p. 143-151).

- "causation is path": cause prepares the path followed by someone or something. This is how cause is conceptualized in Samoan (BERNÁRDEZ, 2008, p. 347-348).

Our popular Western model of causation subjacent to the analytical causative constructions such as fazer/make + Inf or deixar/let + Inf sees causes as forces and causation in a scenery of force dynamics (TALMY, 1988; 2000), in which an entity has a natural tendency and will manifest it unless it is overcomed by another, stronger, entity. Moreover, this model sees the world in terms of a naturalness of things and the course of events and causation as intervention (or absence of intervention) in the "natural course of things". Crucially, the ideology subjacent to the causative constructions is characterized by the popular postulate "Things are as they are unless someone intervenes" (SILVA, 2004; 2005a).

Let us now approach the verbs of perception. Sweetser (1990) suggests that the extension that goes from the meaning of visual perception to the meaning of comprehension is crosslinguistically dominant and even universal. However, Vanhove (2008) recently showed in his typological study about the sources of verbs of mental perception that the semantic association between vision and cognition is not geographically universal but it is, by contrast, restricted to Europe and some parts of Africa.

Finally, the experience of body parts is also culturally specific. The main reason is that what we need to know are not all of the body parts, but the body parts used in activities that have some importance and those than can be affected by some disease. Bernárdez (2008, p. 351-361) shows that in Cha'palaachi (a language from Ecuador), the terms for body parts give more importance to the shapes than to the parts of the body themselves. ${ }^{3}$

Without denying the existence of universal aspects in

${ }^{3}$ See also the studies collected in Sharifian, Dirven, $\mathrm{Yu}$, Niemeier (2008) about the conceptualization of the heart and other internal organs in various languages and cultures. human experience derived from the very body structure that is the same for every human being, one must recognize that these universals are complex and situated and, therefore, culturally and linguistically specific. Thus, Wierzbicka proposes, in 
his extensive investigation on semantic universals (e.g., WIERZBICKA, 1996), an alphabet of human thought ("I", "you", "now", "because", "want", etc.) that cannot be understood as atomistic primitives but as complex primitives; it also cannot be understood as universals detached from culture and language.

\section{Social meaning and lectal variation}

Social meaning incorporates functional, interactional and cultural components and the lectal (geographical, social, stylistic) component of linguistic meaning. Social convention plays an important role in the constitution of linguistic meaning. For example, one of the prototypical features of fruit, namely, the feature of 'generally used as dessert', emerges from our social customs.

Semantic knowledge is unevenly distributed among the members of a linguistic community. According to Putnam (1975), the division of linguistic labor ensures the existence of experts that know, for example, that water is $\mathrm{H}_{2} \mathrm{O}$ and nonexperts that know the stereotype of water, as they have the information that water refers to a natural thing that is a colorless, transparent, tasteless liquid that boils at $100^{\circ}$ Celsius and that freezes when the temperature drops below $0^{\circ}$ Celsius. The stereotype is thus a sociological notion related to the organization of semantic knowledge in society. It is distinguished from the prototype, which is primarily a psychological notion related to the organization of semantic knowledge in an individual's mind. As far as the information of both concepts is the same, stereotypes are prototypes seen from a social perspective.

As the semantic knowledge in a community is heterogeneous, it becomes necessary to investigate which mechanisms guarantee the semantic coordination in a linguistic community and which normative forces determine the distribution of interpretations and also allow for the alteration of the preexistent distribution. Putnam's (1975) principle of division of linguistic labor, also known as semantic deference, is insufficient because not all questions of meaning are socially treated in terms of authority.

By combining the prototype theory, Putnam's (1975) theory of stereotypes and Bartsch's (1987) theory of linguistic 
norms, Geeraerts (2008) identifies the following three types of socio-semantic relations: (i) cooperation, as referred to by Bartsch; (ii) conformity with authority, as described by Putnam; and (iii) conflict. The semantics of cooperation underlie prototypebased extensions of meaning: the new uses of a word satisfy communicative demands and thus fulfill the "highest norm of communication". The semantics of authority are put into action when questions and problems are settled by deference to recognized experts. The semantics of conflict and competition play a role when semantic choices are implicitly questioned or explicitly debated. These three semantic norms sociologically involve collaboration, power and competition and are, to a certain extent, related to three types of social structure, namely, socialism (collaboration-cooperation), authoritarianism (power-authority) and capitalism (competition-conflict).

These three semantic forces allow for a category to develop in different directions. The semantics of cooperation lead to a prototype-based expansion of categories and to flexibility and vagueness. The semantics of authority work in the opposite direction and restrict meaning to expert and essentialist definitions; they are the normative source for precisification. The semantics of conflict occupy an intermediate position to the extent that discussions can lead sometimes to restricting the range of application of a category and sometimes to expanding it. The semantics of cooperation and the semantics of authority both lead to harmony, either from cooperation between equals or from obedience to authority, while the semantics of conflict lead to discordance.

Prototypes, stereotypes and semantic norms are thus integral and interacting components of linguistic meaning. Prototypicality favors flexibility or cognitive and communicative cooperation. However, it also creates conflicts about the interpretation of the meaning of categories. Moreover, prototypicality allows for the restrictive strategy of semantic essentialism, which consists of reducing the meaning of a category to its prototypical core. Take the case of the scandal concerning the relationship between Bill Clinton, ex-President of the United States, and the young White House intern, Monica Lewinsky: Clinton's argument consisted of reducing the concept of 'sexual relation' to its prototypical meaning of sexual intercourse. 
The best manifestation of the social dynamics of meaning is the intralinguistic, lectal variation. Lectal variation has a socially expressive function: it marks pertaining to a group and the social distance and brings recognition of the speaker's attitude relative to the referent of an expression, his/her evaluation of the communicative situation and the interactive intentions of the speaker toward the interlocutor.

It is a fundamental theme of investigation to know how and the extent to which the social aspects and conceptual aspects of lectal variation correlate. This is the object of Cognitive Sociolinguistics (KRISTIANSEN; DIRVEN, 2008; GEERAERTS; KRISTIANSEN; PEIRSMAN, 2010; SILVA, 2009), an emerging extension of Cognitive Linguistics as a usagebased and meaning-oriented approach to language. Cognitive Sociolinguistics constitutes the aforementioned model of the necessary desystematization of the linguistic system, with the finality of describing and explaining language as a complex dynamic system.

Cognitive Sociolinguistics brings specific contributions of the largest importance to both domains of the research on lectal variation, namely, the domain of the variation of meaning, particularly the analysis of the correlation between conceptual factors and social factors of the variation, and the domain of the meaning of the variation or the cognitive representation of lectal variation in its components of perception, categorization and attitudinal evaluation. Cognitive Sociolinguistics fundamentally contributes to the multifactorial model of grammar, which is referred to above as necessary to the description of language as a complex dynamic system and to the analysis of lectal variation inherent to any linguistic expression.

Within the theoretical framework of Cognitive Sociolinguistics, we developed a research project on the diachronic question of convergence or divergence between European Portuguese (EP) and Brazilian Portuguese (BP) in the last 60 years (SILVA 2010; 2012; 2014; 2016). The project uses the onomasiological method in the study of lectal variation and focuses specifically on formal onomasiological variation among denotational synonyms (words or constructions). As mentioned above (in section 4), this variation is particularly interesting from a sociolinguistic perspective because the use 
of denotational synonyms generally provides some hints for the existing relationships between language varieties. The study also uses advanced corpus-based and sociolectometrical methods to measure convergence and divergence and other types of distances between the two national varieties. These measures are based on onomasiological profiles, i.e., sets of alternative synonymous terms or constructions, together with their frequencies. The use of the onomasiological profile-based method allows for a control mechanism to avoid thematic bias in the corpus.

The data for this project was collected from the lexical fields of football and fashion/clothing due to their popularity. Corpus material was extracted from three different sources: (i) sports newspapers and fashion magazines from the 1950s, 1970s and 1990s/2000s; (ii) Internet Relay Chat (IRC) channels related to football (traditional chat fora); and (iii) labels and price tags pictured from shop windows in two Portuguese and Brazilian towns. The subcorpus of football contains 2.7 million tokens selected from 8 newspapers and 15 million tokens collected from Internet chats. The subcorpus of clothing extends to 1.2 million tokens gathered from 24 fashion magazines and 1,300 pictures of labels and price tags photographed from clothes shop windows. These two subcorpora make up the CONDIVport corpus (SILVA, 2008). This corpus is structured according to geographical, diachronic and stylistic variables and has, at present, an extension of 4 million tokens for the formal register (used in sports newspapers and fashion magazines) and 15 million tokens for the informal register (of Internet football chats and clothing labels). The CONDIVport

4 For instance, the onomasiological profile for the concept FORWARD includes the alternative terms atacante, avançado, avante, dianteiro, forward, and ponta-de-lança, and the onomasiological profile for the concept of a BLOUSE for women includes the alternative terms blouse, blusa, blusinha, bustier, camisa, camisa-body, camisão, camiseiro(inho), camiseta/e, (blusa) chémisier, and (blusa) chemisiê. corpus is partly available on the Linguateca website www. linguateca.pt/ACDC (a distributed resource center for language technology for Portuguese).

The sociolexicological analysis was conducted for 43 nominal onomasiological profiles, 21 from football terminology and 22 from clothing vocabulary (SILVA, 2010). ${ }^{4}$ Regarding football, a total number of 183 terms were studied in a database that contains 90,202 observations of these terms used in sports newspapers and 143,946 observations used in Internet chats. For clothing, 264 terms were studied in a database that compiles 12,451 observations used in fashion magazines and 
2,775 observations used in labels and price tags pictured from clothing shops.

Synthesizing the results of the diachronic sociolexicological study, first, the hypothesis of divergence was confirmed in the lexical field of clothing but not in the lexical field of football. Clothing terms are more representative of common vocabulary; therefore, the results obtained for clothing are probably closer to the sociolinguistic reality. The slight convergence observed in the field of football is probably the effect of the globalization and standardization of the vocabulary of football. Second, it seems that there is no specific orientation from one of the varieties towards the other variety, which suggests a situation of symmetric pluricentricity between the two national varieties.

Currently, we intend to examine the extent to which lexical and constructional variables correlate as indicators of convergence/divergence between the two national varieties. The constructional variables include 15 sets of alternative prepositional constructions (such as falar de/sobre/acerca de/em 'to speak of, about'), finite/infinitival complement constructions that involve causative and perception verbs, and noun-adjective/ adjective-noun constructions (such as amigo verdadeiro/verdadeiro amigo, "true friend"). These grammatical variables replicate the clothing lexical variables as indicators of divergence between the two national varieties (SILVA, 2014).

\section{The need for quantitative and multivariational methods}

To describe a language as a complex dynamic system and to describe linguistic meaning as multidimensional, empirical and multivariational, quantitative methods are needed, which are methods of corpus observation, experimental methods, or their combination. It is equally necessary to use lectometric techniques that allow for measuring linguistic distances between lectal varieties, such as diachronic convergence and divergence between them and the internal stratification of lectal varieties.

In relation to elicitation and experimentation methods, the corpus-based method has the advantage of allowing for the observation of actual language usage. In fact, what the speakers think they do with language may not coincide with 
what they actually do with it. Furthermore, by arguing about the complementarity of empirical methods, corpus analysis provides a consistent empirical basis for experimental research. However, an adequate corpus analysis implies great quantities of corpus data and statistical analysis, quantitative and multivariational analysis and advanced techniques. This means that an analysis illustrated by a corpus is insufficient. However, a linguistic investigation will always benefit by the usage of a survey and experimental techniques.

In the field of lectometry - or the measurement of linguistic distances between lectal varieties - three subdomains can be distinguished, namely, dialectometric, stylometric and sociolectometric methods. The more classic tradition of dialectometry has developed advanced techniques for the calculation of linguistic distances between dialects (GOEBL, 2006; NERBONNE; KRETZSCHMAR, 2003). Another lectometric tradition can be found in studies about linguistic registers and consists of the calculation of stylistic differences between them. In this field of stylometry, the so-called multidimensional analysis of Biber (1995) stands out. More recently, and as an extension of the existing lectometric research, sociolectometry comprises methods that allow linguistic distances to be measured and correlated with all types of sociolinguistic variables. More specifically, sociolectometry refers to any lectometric effort to calculate the distances between language varieties that explores the multifactorial nature of linguistic variation and therefore simultaneously analyses lectal varieties that represent several sources of variation. The basis for the calculations is, as seen in the previous section, individual formal onomasiological profiles or profiles, in short. Sociolectometry has been developed by the Quantitative Lexicology and Variational Linguistics (QLVL) research unit as part of its studies on Netherlandic and Belgian Dutch (GEERAERTS; GRONDELAERS; SPEELMAN, 1999; SPEELMAN; GRONDELAERS; GEERAERTS, 2003). By also using statistical and multivariational methods applied to large corpora, the Gries and Stefanowitsch group (GRIES; STEFANOWITSCH, 2006; STEFANOWITSCH; GRIES, 2006; 2008) has developed a collostructional model of great efficacy on the analysis of the correlations between lexical and syntactic variation. 
A number of quantitative techniques can be used for analyzing the correlation between variables. Multivariate techniques of "logistic regression" (PAMPEL, 2000) allow for a rigorous analysis of the correlation between lexical and grammatical variables and sociostylistic and semantic/ structural factors and for determining the impact of these variables/factors. Visualization techniques such as "cluster analysis" (ALDENFELDER; BLASHFIELD, 1984) and "multidimensional scaling" (KRUSKAL; WISH, 1978) are used to trace the discriminative power of (lexical and grammatical) variables and detect multidimensionality. Cluster analysis induces a partition of subcorpora from the dissimilarity matrix in the form of a dendrogram. Multidimensional scaling represents the subcorpora as points in a low-dimensional space in such a way that the distances between the points are as close as possible to the dissimilarities in the matrix. In the field of computational linguistics and its applications to lexical semantics, the well-known "word space models", which are applied to large corpora, enable automatic analysis of the distribution of a word and detect semantic similarities between words automatically (PADÓ; LAPATA, 2007). These mathematical techniques can be applied to both automatic extraction of synonyms and automatic identification of lexical variation between lectal varieties (HEYLEN; PEIRSMAN; GEERAERTS; SPEELMAN, 2008; PEIRSMAN; HEYLEN; GEERAERTS, 2010; PEIRSMAN; GEERAERTS; SPEELMAN, 2010). Crucially, "vector space models" allow for a more rigorous analysis of the correlations between the lectal and conceptual factors of language variation.

\section{Conclusion}

An integrated approach to language and cognition depends on the recognition of the following three interrelated phenomena: (i) the complexity of the linguistic system; (ii) flexibility and other prototypicality effects of linguistic meaning; and (iii) the sociocultural situatedness of human cognition. A usage-based conception of language implies a desystematization of the linguistic system, and the resulting view of language as a complex dynamic system with a multifactorial structure, whether it is external, from the point of view of intralinguistic 
or lectal variation, or internal, according to the perspective of the structure of linguistic phenomena. If we assume that meaning, structure, discourse and lectal variation all codetermine language phenomena, then we need a multivariate model of language.

Prototypicality, or the prototype-based conception of categorization, and other phenomena of lexical and grammatical salience, such as radial semantic networks and onomasiological salience, make the linguistic meaning dynamic, flexible and multidimensional and make language a dynamic, adaptable, complex and multisystemic system. As they are categories that enable us to give meaning to the world, the meanings of words and constructions are categories of our individual, collective and historical experience. The linguistic phenomena of polysemy and semantic change and the psychological and psycholinguistic phenomena of perception, memorization, language acquisition and language development are evidence that our categorization of the world is anchored in prototypes. Prototypicality is the manifestation of cognitive efficiency. As a phenomenon of psychological salience, prototypicality is linked to sociological salience or stereotypicality and to the socio-semantic norms of cooperation, authority and conflict on meaning distribution in a linguistic community. Prototypicality not only favors cognitive and communicative cooperation but also engenders interpretative conflicts.

The notion of image schema, which is foundational for Cognitive Semantics, and the semantics of spatial expressions show that even the most spatial meanings integrate perceptive, kinetic and interactional aspects. Sensorial perception is therefore not disconnected from motor action and social interaction, as perceiving the world is (inter)acting with it, as Merleau-Ponty (1945) has pointed out. The hypothesis of embodiment, which is foundational to the second generation of cognitive sciences, has to expand its original focus on the bodily experience (as opposed to the social experience) to incorporate the more recent notion of the sociocultural situatedness of cognition. The neurophysiological and universalist conception of cognition is thus abandoned so that cognition can be understood as a situated, distributed, synergic and social process. 
Cognitive Linguistics, through Cognitive Semantics and emerging lines of research that are more compromised by the sociocognitive view of language, such as Cognitive Sociolinguistics, offers important paths to the view of language as a complex dynamic system, to the analysis of meaning variation in all its dimensions and to the exploration of the interaction among the conceptual, social, perceptive and (inter) actional factors of language and cognition.

\section{REFERENCES}

ALDENFELDER, M.; BLASHFIELD, R. Cluster Analysis. Newbury: Sage Publications, 1984.

BALDINGER, K. Sémasiologie et onomasiologie. Revue de Linguistique Romane 28, p. 249-272, 1964.

BARTSCH, R. Norms of Language. Theoretical and Practical Aspects, London: Longman, 1987.

BERNÁRDEZ, E. Intimate enemies? On the relations between language and culture. In: A. Soares da Silva, A. Torres, M. Gonçalves (Eds.), Linguagem, Cultura e Cognição: Estudos de Linguística Cognitiva. Vol. I. Coimbra: Almedina, p. 21-45, 2004.

BERNÁRDEZ, E. Social cognition: variation, language, and culture in a cognitive linguistic typology. In: F. J. Ruiz de Mendoza, S. Peña Cervel (Eds.), Cognitive Linguistics. Internal Dynamics and Interdisciplinary Interaction. Berlin: Mouton de Gruyter, p. 191-222, 2005

BERNÁRDEZ, E. Collective cognition and individual activity: Variation, language and culture. In: R. M. Frank, R. Dirven, T. Ziemke, E. Bernárdez (Eds.), Body, Language, and Mind. Volume 2. Sociocultural Situatedness. Berlin: Mouton de Gruyter, p. 137-166, 2008a.

BERNÁRDEZ, E. El Lenguaje como Cultura. Una Crítica del Discurso sobre el Lenguaje. Madrid: Alianza Editorial, 2008b.

BIBER, D. Dimensions of Register Variation: A Cross-Linguistic Comparison. Cambridge: Cambridge University Press, 1995. 
CHAMBERS, J. K.; TRUDGILL, P. Dialectology. Cambridge: Cambridge University Press, 1998.

CLARK, A. An embodied cognitive science. Trends in Cognitive Science, v. 3, n. 9, p. 345-351, 1999.

CLARK, H. H. Space, time, semantics and the child. In T. E. Moore (ed.), Cognitive Development and the Acquisition of Language. New York: Academic Press, 27-63, 1973.

COLEMAN, L.; KAY, P. Prototype semantics: The English word lie. Language 57, p. 26-44, 1981.

COLLEMAN, T. Lectal variation in constructional semantics: "Benefactive" ditransitives in Dutch. In: D. Geeraerts, G. Kristiansen, Y. Peirsman (Eds.), Advances in Cognitive Sociolinguistics. Berlin: Mouton de Gruyter, p. 191-221, 2010.

CORREA-BENINGFIELD, M.; KRISTIANSEN, G.; NAVARROFERRANDO, I.; VANDELOISE, C. Image schemas vs. Complex Primitives in cross-cultural spatial cognition. In B. Hampe (Ed.), From Perception to Meaning. Image Schemas in Cognitive Linguistics. Berlin: Mouton de Gruyter, p. 343-366, 2005.

DAMÁSIO, A. O Erro de Descartes. Emoção, Razão e Cérebro Humano. Mem Martins: Publicações Europa-América, 1995.

DAMÁSIO, A. O Sentimento de Si. O Corpo, a Emoção e a Neurobiologia da Consciência. Mem Martins: Publicações Europa-América, 2000.

DEANE, P. At, by, to, and past: An essay in multimodal image theory. Berkeley Linguistics Society 19, p. 112-124, 1993.

EDELMAN, G. M. Bright Air, Brilliant Fire: On the Matter of the Mind. New York: Basic Books, 1992.

FRANK, R. M.; DIRVEN, R.; ZIEMKE, T.; BERNÁRDEZ, E. (Eds.). Body, Language, and Mind. Volume 2. Sociocultural Situatedness. Berlin: Mouton de Gruyter, 2008.

GEERAERTS, D. Paradigm and Paradox. Explorations into a Paradigmatic Theory of Meaning and its Epistemological Background. Leuven: Leuven University Press, 1985. 
GEERAERTS, D. Where does prototypicality come from? In: B. Rudzka-Ostyn (ed.), Topics in Cognitive Linguistics. Amsterdam: John Benjamins, p. 207-229, 1988.

GEERAERTS, D. Diachronic Prototype Semantics. A Contribution to Historical Lexicology. Oxford: Clarendon Press, 1997.

GEERAERTS, D. Prototypes, stereotypes and semantic norms. In: G. Kristiansen, R. Dirven (Eds.), Cognitive Sociolinguistics: Language Variation, Cultural Models, Social Systems, Berlin: Mouton de Gruyter, p. 21-44, 2008.

GEERAERTS, D. Theories of Lexical Semantics. Oxford: Oxford University Press, 2010a.

GEERAERTS, D. Schmidt redux: How systematic is the linguistic system if variation is rampant? In: K. Boye, E. Engeberg-Pedersen (Eds.), Language Usage and Language Structure. Berlin: Mouton de Gruyter, p. 237-262, $2010 \mathrm{~b}$.

GEERAERTS, D.; GRONDELAERS, S.; BAKEMA, P. The Structure of Lexical Variation. Meaning, Naming, and Context. Berlin: Mouton de Gruyter, 1994.

GEERAERTS, D.; GRONDELAERS, S.; SPEELMAN, D. Convergentie en divergentie in de Nederlandse woordenschat. Amsterdam: Meertens Instituut, 1999.

GEERAERTS, D.; CUYCKENS, H. (Eds.). The Oxford Handbook of Cognitive Linguistics. Oxford/New York: Oxford University Press, 2007.

GEERAERTS, D.; KRISTIANSEN, G.; PEIRSMAN, Y. (Eds.). Advances in Cognitive Sociolinguistics. Berlin: Mouton de Gruyter, 2010.

GEERAERTS, D.; SPEELMAN, D. Heterodox concept features and onomasiological heterogeneity in dialects. In: D. Geeraerts, G. Kristiansen, Y. Peirsman (Eds.), Advances in Cognitive Sociolinguistics. Berlin: Mouton de Gruyter, p. 23-39, 2010.

GIBBS, R. W. Embodiment and Cognitive Science. Cambridge: Cambridge University Press, 2005. 
GOEBL, H. Recent advances in Salzburg dialectometry. In: J. Nerbonne, W. Kretzschmar (Eds.), Literary and Linguistic Computing, special issue on Progress in Dialectometry: Toward Explanation. Oxford: Oxford University Press, p. 411-435, 2006.

GRIES, St. Th.; STEFANOWITSCH, A. (Eds.). Corpora in Cognitive Linguistics. Corpus-based Approaches to Syntax and Lexis. Berlin: Mouton de Gruyter, 2006.

HAMPE, B. (Ed.). From Perception to Meaning. Image Schemas in Cognitive Linguistics. Berlin: Mouton de Gruyter, 2005.

HARDER, P. Meaning in Mind and Society: A Functional Contribution to the Social Turn in Cognitive Linguistics. Berlin: Mouton de Gruyter, 2010.

HEYLEN, K.; PEIRSMAN, Y.; GEERAERTS, D.; SPEELMAN, D. Modelling word similarity. An evaluation of automatic synonymy extraction algorithms. In: Proceedings of the Language Resources and Evaluation Conference (LREC-2008). Marrakech, Morocco, 2008.

JOHNSON, M. The Body in the Mind: The Bodily Basis of Meaning, Imagination, and Reason. Chicago: The University of Chicago Press, 1987.

KRISTIANSEN, G.; DIRVEN, R. (Eds.). Cognitive Sociolinguistics: Language Variation, Cultural Models, Social Systems. Berlin: Mouton de Gruyter, 2008.

KRUSKAL, J.; WISH, M. Multidimensional Scaling. Newbury: Sage Publications, 1978.

LABOV, W. Sociolinguistic Patterns. Philadelphia: University of Pennsylvania Press, 1972.

LABOV, W. Where does the sociolinguistic variable stop? A response to Beatriz Lavandera. Working Papers in Sociolinguistics 44. Austin: Southwest Educational Development Laboratory, 1978.

LAKOFF, G.; JOHNSON, M. Metaphors We Live By. Chicago: The University of Chicago Press, 1980. 
LAKOFF, G.; JOHNSON, M. Philosophy in the Flesh: The Embodied Mind and its Challenge to Western Thought. New York: Basic Books. 1999.

LANGACKER, R. W. (1987). Foundations of Cognitive Grammar. Vol. 1: Theoretical Prerequisites. Stanford: Stanford University Press.

LANGACKER, R. W. Foundations of Cognitive Grammar. Vol. 2: Descriptive Application. Stanford: Stanford University Press, 1991.

LANGACKER, R. W. Cognitive Grammar. A Basic Introduction. Oxford: Oxford University Press, 2008.

LAVANDERA, B. Where does the sociolinguistic variable stop? Language in Society 7, p. 171-183, 1978.

NERBONNE, J.; KRETZSCHMAR, W. Introducing computational methods in Dialectometry. In: J. Nerbonne, W. Kretzschmar (Eds), Computational Methods in Dialectometry, Special issue of Computers and the Humanities. Oxford: Oxford University Press, p. 245-255, 2003.

MERLEAU-PONTY, M. The Phenomenology of Perception. Atlantic Highlands, NJ: Humanities Press, 1945.

PADÓ, S.; LAPATA, M. Dependency-based construction of semantic space models. Computational Linguistics 33 (2), p. 163199, 2007.

PAMPEL, F. Logistic Regression. A Primer. Thousand Oaks: Sage Publications, 2000.

PEIRSMAN, Y.; GEERAERTS, D.; SPEELMAN, D. The automatic identification of lexical variation between language varieties. Natural Language Engineering, v. 16, n. 4, p. 469-490, 2010.

PEIRSMAN, Y.; HEYLEN, K.; GEERAERTS, D. Applying word space models to sociolinguistics. Religion names before and after 9/11. In: D. Geeraerts, G. Kristiansen, Y. Peirsman (Eds.), Advances in Cognitive Sociolinguistics. Berlin: Mouton de Gruyter, p. 111-137, 2010. 
PISHWA, H. (Ed.). Language and Social Cognition. Expression of the Social Mind. Berlin: Mouton de Gruyter, 2009.

PUTNAM, H. The meaning of meaning. In: K. Gunderson (Ed.), Language, Mind and Knowledge. Minnesota: University of Minnesota Press, p. 131-193, 1975.

ROHRER, T. Embodiment and experientialism. In: D. Geeraerts, H. Cuyckens (Eds.), The Oxford Handbook of Cognitive Linguistics. Oxford: Oxford University Press, 25-47, 2007.

ROSCH, E. Principles of categorization. In: E. Rosch, B. B. Lloyd (Eds.), Cognition and Categorization. Hillsdale: Lawrence Erlbaum, p. 27-48, 1978.

SHARIFIAN, F.; DIRVEN, R.; YU, N.; NIEMEIER, S. (Eds.) Culture, Body, and Language. Conceptualizations of Internal Body Organs across Cultures and Languages. Berlin: Mouton de Gruyter, 2008.

SILVA, A. S. da. A Semântica de DeIXAR. Uma Contribuição para a Abordagem Cognitiva em Semântica Lexical. Lisboa: Fundação Calouste Gulbenkian e Fundação para a Ciência e a Tecnologia, 1999.

SILVA, A. S. da. Image schemas and category coherence: The case of the Portuguese verb deixar. In: H. Cuyckens, R. Dirven, J. R. Taylor (Eds.), Cognitive Approaches to Lexical Semantics. Berlin: Mouton de Gruyter, p. 281-322, 2003.

SILVA, A. S. da. Cultural determinations of causation. In: A. Soares da Silva, A. Torres, M. Gonçalves (Eds.), Linguagem, Cultura e Cognição: Estudos de Linguística Cognitiva. Vol. 1 Coimbra: Almedina, p. 575-606, 2004.

SILVA, A. S. da. Semântica e cognição da causação analítica em português. In: N. Salim, M. Cristina Name (Orgs.), Lingüística e Cognição. Juiz de Fora: Universidade Federal de Juiz de Fora, p. 11-47, 2005a. 
SILVA, A. S. da. Revisitando as construções causativas e perceptivas do Português: significado e uso. In: I. Duarte, I. Leiria (Eds.), Actas do XX Encontro Nacional da Associação Portuguesa de Linguística. Lisboa: Associação Portuguesa de Linguística, p. 855-874, 2005b.

SILVA, A. S. da. O Mundo dos Sentidos em Português: Polissemia, Semântica e Cognição. Coimbra: Almedina, 2006.

SILVA, A. S. da. O corpus CONDIV e o estudo da convergência e divergência entre variedades do português. In: L. Costa, D. Santos, N. Cardoso (Eds.), Perspectivas sobre a Linguateca/Actas do Encontro Linguateca: 10 anos. Disponível em <http://www. linguateca.pt/LivroL10/>. Acesso em: 30 set. 2019, 2008

SILVA, A. S. da. A Sociolinguística Cognitiva: razões e objecto de uma nova área de investigação linguística. Revista Portuguesa de Humanidades: Estudos Linguísticos, v. 13 n. 1, p. 191-212., 2009.

SILVA, A. S. da. Measuring and parameterizing lexical convergence and divergence between European and Brazilian Portuguese. In: D. Geeraerts, G. Kristiansen, Y. Peirsman (Eds.), Advances in Cognitive Sociolinguistics. Berlin: Mouton de Gruyter, p. 41-83, 2010.

SILVA, A. S. da. Comparing objective and subjective linguistic distances between European and Brazilian Portuguese. In: M. Reif, J. A. Robinson, M. Pütz (Eds.), Variation in Language and Language Use: Linguistic, socio-cultural and cognitive perspectives. Frankfurt: Peter Lang, p. 244-274, 2012.

SILVA, A. S. da. The pluricentricity of Portuguese: A sociolectometrical approach to divergence between European and Brazilian Portuguese. In: A. Soares da Silva (Ed.), Pluricentricity: Language Variation and Sociocognitive Dimensions. Berlin: Mouton de Gruyter 143-188, 2014.

SILVA, A. S. da. The cognitive approach to pluricentric languages and the pluricentricity of Portuguese: What's really new? In: R. Muhr (Ed.), Pluricentric Languages and Non-Dominant Varieties Worldwide. Part II: The Pluricentricity of Portuguese and Spanish. New Concepts and Descriptions. Wien: Peter Lang Verlag, p. 13-34, 2016. 
SINHA, C. Language as a biocultural niche and social institution. In: V. Evans, S. Pourcel (Eds.), New Directions in Cognitive Linguistics. Amsterdam: John Benjamins, p. 289-309, 2010.

SPEELMAN, D.; GRONDELAERS, S.; GEERAERTS, D. Profilebased linguistic uniformity as a generic method for comparing language varieties. Computers and the Humanities 37, p. 317-337, 2003.

STEFANOWITSCH, A.; GRIES, St. Th. Corpus-based Approaches to Metaphor and Metonymy. Berlin: Mouton de Gruyter, 2006.

STEFANOWITSCH, A.; Gries, St. Th. (2008). Channel and constructional meaning: A collostructional case study. In: G. Kristiansen, R. Dirven (Eds.). Cognitive Sociolinguistics: Language Variation, Cultural Models, Social Systems. Berlin: Mouton de Gruyter, p. 129-152, 2008.

SWEETSER, E. From Etymology to Pragmatics. Metaphorical and Cultural Aspects of Semantic Structure. Cambridge: Cambridge University Press, 1990.

SZMRECSANYI, B. The English genitive alternation in a cognitive sociolinguistics perspective. In: D. Geeraerts, G. Kristiansen, Y. Peirsman (Eds.), Advances in Cognitive Sociolinguistics. Berlin: Mouton de Gruyter, p. 141-166, 2010.

TALMY, L. How language structures space. In: H. Pick, L. Acredolo (Eds.), Spatial Orientation: Theory, Research, and Application. New York: Plenum Press, p. 225-282, 1983.

TALMY, L. Force dynamics in language and cognition. Cognitive Science 12, p. 49-100, 1988.

TALMY, L. Toward a Cognitive Semantics. Vol. 1: Concept Structuring Systems. Vol. II: Typology and Process in Concept Structuring. Cambridge: The MIT Press, 2000.

TAYLOR, J. R. Linguistic Categorization. Prototypes in Linguistic Theory. Oxford: Oxford University Press, 1995. 
TURNER, M. Death is the Mother of Beauty: Mind, Metaphor, Criticism. Chicago: The University of Chicago Press, 1987.

VANDELOISE, C. Spatial Prepositions: A Case Study from French. Chicago: The University of Chicago Press, 1991.

VANDELOISE, C. Containment, support and linguistics relativity. In: H. Cuyckens, R. Dirven, J. R. Taylor (Eds.), Cognitive Approaches to Lexical Semantics. Berlin: Mouton de Gruyter, p. 393-426, 2003.

VANHOVE, M. Semantic associations between sensory modalities, prehension and mental perceptions: A crosslinguistic perspective. In: M. Vanhove (Ed.), From Polysemy to Semantic Change. Towards a Typology of Lexical Semantic Associations. Amsterdam: John Benjamins, p. 341-370, 2008.

VARELA, F.; THOMPSON, E.; ROSCH, E. The Embodied Mind. Mass.: Massachusetts Institute of Technology, 1991.

WIERZBICKA, A. Semantics. Primes and Universals. Oxford: Oxford University Press, 1996.

WILSON, R. A. Boundaries of the Mind. The individual in the fragile sciences. Cambridge: Cambridge University Press, 2005.

WITTGENSTEIN, L. Philosophical Investigations. Oxford: Basil Blackwell, 1953.

ZIEMKE, T.; ZLATEV, J.; FRANK, R. (Eds.). Body, Language, and Mind I: Embodiment. Berlin: Mouton de Gruyter, 2007.

ZLATEV, J. Situated Embodiment: Studies in the Emergence of Spatial Meaning. Stockholm: Gotab, 1997.

ZLATEV, J. Embodiment, language and mimesis. In: T. Ziemke, J. Zlatev, R. M. Frank (Eds.), Body, Language and Mind. Vol. 1. Embodiment. Berlin: Mouton de Gruyter, p. 297-337, 2007.

ZLATEV, J.; RACINE, T.; SINHA, C.; ITKONEN, E. (Eds.). The Shared Mind: Perspectives on Intersubjectivity. Amsterdam: John Benjamins, 2008. 


\section{Resumo}

Complexidade, variação e significado: uma visão integrada sobre linguagem e cognição

A complexidade do sistema linguístico, a variabilidade do significado e a interindividualidade da cognição humana estão intimamente relacionadas. Ao examinar a linguagem em seu uso efetivo, não podemos deixar de reconhecer sua grande variabilidade e heterogeneidade, e é preciso correlacionar a variação social com a variação conceitual. Ao investigar a variabilidade do significado, não se pode negligenciar a variação sociolinguística como um dos fatores dessa variabilidade, e tornase inevitável encontrar a multidimensionalidade do significado na confluência de suas dimensões sociais e conceituais e na correlação entre percepção, ação e interação. Compreender a cognição como situada socioculturalmente torna inevitável a integração dos aspectos sociais, culturais e interacionais na análise, não apenas das capacidades cognitivas em geral, mas também da linguagem. Neste estudo, procuramos articular a ideia de linguagem como um sistema dinâmico complexo com a constatação da flexibilidade intrínseca do significado linguístico, que tem a prototipicidade como uma de suas maiores manifestações, e identificamos a necessidade de integração de aspectos conceituais e sociais da linguagem e cognição. Seguimos o arcabouço teórico da Linguística Cognitiva e defendemos a necessidade de métodos multivariados avançados que possam abordar adequadamente a linguagem como um sistema dinâmico complexo e uma multidimensionalidade do significado linguístico.

Palavras-chave: sistema dinâmico complexo; variação de significado; prototipicidade; cognição situada; métodos multivariados. 